\title{
DISCO IMPERIÓW. CZESŁAW MIŁOSZ I PRZYSZtOŚĆ KULTURY
}

\author{
Mikołaj Golubiewski
}

$/ / / 1$.

Dla Czesława Miłosza pisanie fantastyki naukowej jest wypełnianiem zadania stałego poszukiwania „,formy bardziej pojemnej” - która głosi w swoim wierszu poetologicznym Ars poetica? (1968) - czyli przedstawiania stałej treści w coraz to nowych formach i z nowych punktów widzenia, które przecież nigdy nie ustanowią boskiego wszechoglądu rzeczy. Stąd Góry Parnasu. Science fiction może nie być - i nie jest - powieścia, nie mieć żadnej akcji, a właściwie tylko alegoryczne fragmenty umiejscowione w przyszłości, czyli prognozy o kierunkach rozwoju współczesnej kultury. Stanley Bill we wstępie do swojego angielskiego przekładu zwraca uwage, że mimo to tekst Miłosza jest przecież ćwiczeniem w spekulacyjnym tworzeniu światów (Bill 2017: XV). Niestety od publikacji w roku 2012 ujmowano ten tekst jedynie w ramy refleksji religijnej (Zioło 2014), gnostyckiej dystopii (Garbol 2014, Miklas-Frankowski 2014, Jarzyńska 2013) czy religijnego konformizmu (Bielik-Robson 2013), co zamyka lekturę w dominującym w Polsce, niemal wyłącznie religijnym spojrzeniu na dzieło Miłosza. Bez wątpienia przyczyniło się do tego niezwykle wartościowe wprowadzenie do książki pióra Agnieszki Kosińskiej. Jej refleksję analizuję krytycznie, traktując owo wprowadzenie jako świetny wstęp do dyskusji o materiale mniej jednoznacznym, niż można by wnioskować z opisów jej czy Sławomira Sierakowskiego, a które przecież od razu towarzyszą książce, sugerując jedyne właściwe odczytanie. Dlatego też niniejsza lektura bardziej niż na stronie religijnej czy eschatologicznej tej powieści skupia się na wątkach prognostykujących o przyszłości kultury. Uważam bowiem, że wbrew wcześniejszym interpretacjom Góry Parnasu są przede wszystkim rewizja 
stanu kultury i prorokowaniem o jej przyszłości z perspektywy pojedynczego poety, choć ujętym w globalne ramy. W tym celu rozważam, co właściwie Miłosz mówi o przyszłości i co Kosińska pomija w swojej refleksji, ale przede wszystkim zastanawiam się nad tym, co w polskiej tradycji znaczy „prorokowanie”, w które wpisuje się nienapisana książka noblisty.

\section{/// 2.}

Krytyka Polityczna opublikowała nieukończona powieść Czesława Miłosza Góry Parnasu. Science fiction w roku 2012, osiem lat po śmierci poety. Ów pracował nad tekstem w latach 1965 i 1967 oraz przez cały urlop akademicki w Berkeley (1970-1971). Powieść pseudonimuje znanych z historii bohaterów i instytucje. II wojna światowa to Wojna Miłośników Rasowego Pokoju. Kontrkulturę lat 60. XX wieku można odnaleźć w cechach Stowarzyszenia Podpalaczy, którzy walczą bez celu i uzasadnienia, paląc laboratoria i biblioteki. Znajdziemy także pokolenie tzw. intelektualistów, którzy „ciekawscy o zręcznych palcach, rozbierali na kawałki swoją filozoficzną zabawkę" (Miłosz 2012: 34). Można tę grupę porównać do francuskich (post) strukturalistów, u których Miłosz nie zaznał gościny ${ }^{1}$. Atmosfera zimnej wojny obecna jest w rywalizacji między potężnymi Związkami Botaników i Astronautów. Poeta dokłada do tego elementy magiczne w celu wypełnienia zasad gatunku science fiction - bo przecież większość popularnych książek gatunku nie realizuje wymogów refleksji naukowej i kładzie nacisk na fantastykę - ale nie pisze żadnych dialogów. Książka krytykuje rozrywkę jako część systemu imperialnego. Autor pisze równocześnie o USA i ZSSR, w których odnajduje podobieństwo problemów społecznej standaryzacji. Używa w tym celu gatunku fantastyki naukowej, czyli powieści popularnej, choć właśnie kulturę popularną uważa za projekt przegrany i odgórnie narzucone opium dla zaniepokojonych społeczną standaryzacją. Jako odtrutkę proponuje życie w odseparowanej wspólnocie religijnej. Książkę dopełniają osobne omówienia Sławomira Sierakowskiego i Agnieszki Kosińskiej. Sierakowski doszukuje się w tekście opisu chorób nowoczesności, a Kosińska proponuje jej katolicką interpretację jako profetyczną dystopię o kierunku rozwoju cywilizacji Zachodu.

\footnotetext{
1 Wystarczy przypomnieć fragment jego wiersza Strukturalista z 1967: „Byłem na odczycie strukturalisty, mówił nadzwyczaj inteligentnie i jego francuskie łapki nadzwyczaj inteligentnie trzymały papierosa / Chciałem wstać i powiedzieć: ty, na tej ziemi wycia i rzygowin, na tej ziemi dręczonego wszelkiego żywego stworzenia i mojej ludzkiej rozpaczy, ty, naukowcu, świnio” (Miłosz 2015: 561).
} 


\section{/// 3.}

Agnieszka Kosińska jednoznacznie łączy Miłosza z bohaterem powieści Efraimem, odpornym na kontrolę umysłu założycielem odizolowanej wspólnoty Parnas. Fragmentaryczna powieść Góry Parnasu jest jednak niewątpliwie wielogłosowa. Zatem niełatwo powiedzieć, że jedna z postaci dominuje nad resztą, co sprawia, że trudno zgodzić się z utożsamieniem Kosińskiej. W tym celu dołącza do powieści materiał już wcześniej drukowany, czyli Liturgie Efraima (Miłosz 1968) i sugeruje, że „[p]o druku pracował nad [Liturgia Efraima]" - czego niestety nie sposób jednoznacznie ustalić - oraz że „zdaje się, że to ona była jądrem i osią planowanego utworu science fiction" (Kosińska 2012: 113), co ponownie nieugruntowane jest w żadnym materiale dowodowym. A przecież takie postawienie sprawy umacnia interpretację całości zgodnie z wątkiem uwypuklającym postać Efraima, który ma być - jak pisze Kosińska - „odnowicielem języka i rytuału religijnego” (2012: 114). Sugestia łączności „Miłosz-Efraim”, którą Kosińska zawiera w podtytule, jest zasadna o tyle (2012: 112), o ile zasadna jest bliskość każdego bohatera powieści jako instancji momentu biograficznego Miłosza lub fragmentu jego spojrzenia na rzeczywistość. W tym zakresie interesować nas powinna jednak najbardziej postać Astronauty. Zreszta - wbrew Kosińskiej - część Opowieść Astronanty zajmuje najwięcej miejsca w Górach Parnasu, jedną trzecią (dwadzieścia stron), i tylko dołączenie wcześniej publikowanej Liturgii Efraima - jakkolwiek trafne - nadaje więcej ciężaru temu drugiemu. Tym niemniej, jako najbliższa gatunkowi fantastyki naukowej i umiejscowiona w punkcie klamrowym, na końcu zbioru fragmentów, Opowieść Astronauty kompozycyjnie zajmuje w nieukończonym dziele pozycję dominująca.

Ponadto, Kosińska wskazuje, że czytelnicy Miłosza mogą być przyzwyczajeni do wysoce intelektualnych rozważań skoncentrowanych na sprawach społeczno-politycznych, podczas gdy jej zdaniem Miłosz nie mógłby mocniej wyrazić własnego przeświadczenia o nadciagającej apokalipsie, niż robi to w Górach Parnasu. Kosińska zwraca uwagę, że podczas pierwszego pobytu w USA (1945-1949) Miłosz rozmyślał nad przyłączeniem się do wspólnoty Primavera tworzonej w paragwajskich lasach przez huterytów, izolacjonistyczny odłam anabaptystów. Ten fakt jednak prowadzi mnie ku odmiennym interpretacjom niż Kosińską, która podkreśla kwietystyczne ciagoty Miłosza. Ta samotnicza potrzeba w pisaniu poety ujawnia się w Górach Parnasu, ale po ponad dwudziestu latach od zainteresowania Primavera nie jest przecież jedynym wątkiem, skoro główną motywacją narratora jest 
pragnienie uzdrowienia całej ludzkości przez powrót do życia wspólnotowego, co - jak do tej pory - realizuje postać Efraima.

Bez wattpienia jednak odpowiedź Miłosza na obezwładniającą racjonalność nowoczesności - życie wspólnotowe - ma nas chronić przed powszechnym światem bez transcendencji, który w Górach Parnasu kierunkuje ludzi wyłącznie ku temu, co cielesne i zwierzęce. Znajdujemy to podejście w gnostyckiej refleksji kardynała Vallergi, którego zapiski z XX wieku - czyli w powieściowym świecie antycznym - czyta Efraim: „choroba, śmiertelną, jest instynkt ze skazą świadomości i świadomość ze skazą instynktu”, a kilka stron dalej wyjaśnia, że z tego powodu wielu „,nawet Freuda poprawia[ło] tam, gdzie zbyt pesymistycznie oceniał możliwość triumfu człowieka naturalnego" (Miłosz 2012: 50, 57). Wówczas kardynał Vallerga nazywa podległych kontroli społecznej ważnym słowem w słowniku Miłosza - „daimonizomenoi” (59) - które objaśnia jego wiersz Lektury z tego samego okresu (1973): „Pełno było tych, których w tekście [Biblii] się nazywa / Daimonizomenoi, czyli biesujacych / Albo i biesowatych (bo «opętanymi» / Język nasz ich mianuje tylko z fantazji słownika)" (Miłosz 2015: 623). Oni to właśnie tańczą disco albo podskakuja do rocka - zaledwie powstałych stylów muzycznych - co Kardynał opisuje krytycznie: „,[za kościołem] krzepiła się rytmicznym klaskaniem w dłonie ich uśmiechnięta, postępowa rozsądność, bełkotali i miotali się w drgawkach” (Miłosz 2012: 59).

\section{$/ / / 4$.}

Protagoniści Gór Parnasu chcą wybawić siebie od bezcelowego życia. Miłosz oferuje im drogę wyjścia przez pogodzenie się z czasem i uobecnienie perspektywy śmierci. Powieściowi ludzie zatracają się w disco w celu budowania sztucznych wspólnot i rajów, które jednak wyniszczają autentyczną kulturę - czytamy - bo moga ją tworzyć wszyscy, a nie przyjmuje nikt. Wobec tego narrator argumentuje, że nie sposób uratować ludzkości, póki nie przewartościuje ona swojej postawy wobec czasu. Bez uświęcenia wymiarów przestrzeni i czasu - wymiarów istnienia - stają się bowiem jedynie pasażerami na bezcelowym globie. Metafora kuli ziemskiej jako statku kosmicznego każe nabrać dystansu wobec indywidualnych wysiłków lekceważenia upływu czasu.

Ziemia płynęła czy wirowała, czy sunęła, jakkolwiek to nazwiemy, tak jak sztuczne ziemie uwięzione w swoich orbitach, a jej pasażerowie zajmowali się tym, co język malowniczo, choć lekkomyślnie 
określił jako zabijanie czasu, nie przewidując (jeżeli język może przewidywać), jak groźnego nabierze to znaczenia. Czas przerażał i obrażał, należało go zniszczyć i zastąpić intensywnością doznań każdej chwili, tak żeby wiele mogło się zdarzyć, zanim wskazówki zegarka wskażą upływ minuty. [...] Rzecz dziwna, każdego niemal z Ziemian dręczyło poczucie, że dla innych czas tracił swoja jadowitą monotonię, że inni czują i czując, wyzwalają się spod władzy minut i godzin, on tylko nic nie czuje, że inni są włączeni w wielkie coś, on tylko jest wyłączony (Miłosz 2012: 32-33).

Miłosz opisuje w tym fragmencie świat, w którym bezrefleksyjna konsumpcjocentryczna egzystencja prowadzi do atrofii kontaktów interpersonalnych i języka, czyli poważnego poluzowania więzi społecznych. Atrofia wymazuje wszelkie niepokoje prócz poczucia bezcelowości, które jednak następnie odbiera energię życiową i wzmaga tendencje samobójcze. Jak ujmuje to narrator, ironizując $\mathrm{z}$ anglosaskiego powitania How are you?: „Mieszkańcy ziemskiego państwa, jeżeli komunikowali się ze sobą, to tylko żeby pytać "co czujesz?»" (2012: 32). Kosińska przypomina, że w liście do Andrzejewskiego Miłosz deklaruje, że w Ameryce: „stosunki ludzkie sa rozrzedzone, sprowadzone do paru najprostszych elementów i gdzie normalnie tysiące mil dzielą każdego od miejsca jego urodzenia czy jakichś dawnych przeżyć" (Andrzejewski, Miłosz 2011: 194).

Chłodna refleksja narratora dotyczy zarówno Stanów Zjednoczonych, jak i Związku Radzieckiego ${ }^{2}$. Z jednej strony, wiele krajobrazów książki jest niewątpliwie amerykańskich, inspirowanych krajobrazem kalifornijskim (Miłosz 2012: 28-30). Krytyczne wzmianki narratora silnie nawiązują do kontrkultury lat 60. XX wieku, która w jego oczach wyglądała następująco: „[wielu było] wariatów jawnych, biegających naokoło z kwiatami we włosach"; których wcześniej jeszcze opisuje, zasłaniając się elitarystyczna postawą francuskiego pisarza: ,,[o nich] poeta Baudelaire mawiał, że fornikacja jest poezją liryczną ludu, okazywał przez to swoją pogardliwą sympatię warstwom niższym, które, pozbawione dostępu do wyższych zatrudnień ducha, otrzymywały pociechę w swoim ciele, co było sprawiedliwe” (2012: 40,33). Kosińska odnajduje potwierdzenie tych przemyśleń w liście

\footnotetext{
${ }^{2}$ Pod koniec lat 50. Miłosz opracował antologię tekstów Kultura masowa, a we wstępie przedstawił swój stosunek do tego zjawiska. Omawiając ten zbiór tekstów i wstęp Miłosza, Ewa Kołodziejczyk (2001: 116) trafnie podkreśla, że już wówczas poeta sugerował bliskość kultury masowej i socrealizmu, choć biorą się z różnych potrzeb. Pierwsza dla biznesu, a druga dla kontroli społecznej. Moim zdaniem Góry Parnasu sugerują, że oba nurty zawierają nutę kontroli społecznej i są narzędziem szerzej pojętych imperializmów.
} 
Miłosza do Giedroycia, gdzie ten pierwszy wprost deklaruje, że „prasa i telewizja jako lewicowe brain-washing wykracza już poza wszelkie miary, co tu dziwić się młodym kudłatym małpom” (Giedroyc, Miłosz 2011: 460).

Z drugiej strony, wiele aluzji przywołuje Związek Radziecki, zwłaszcza jeżeli przyjmiemy za tło u Miłosza pseudonimowanie skompromitowanych intelektualistów komunistycznej Polski w Zniewolonym umyśle według liter alfabetu greckiego, co w Górach Parnasu ujawniają aluzje o prądzie Alfa i Beta w opowieści Astronauty (Miłosz 2012: 64). Postać Astronauty odpowiada opisom wielu takich figur. Jak sam twierdzi, „[u]tożsamiałem się całkowicie ze Związkiem [...] [i z tym, co d]awniej uroczyście zapowiadano, że stworzy się nowego człowieka i każda kucharka będzie umiała zarządzać państwem” (Miłosz 2012: 65-66). Ten obraz przywołuje wielkie projekty radzieckie, które obecne są także we fragmencie o początkach globalnego pokoju. Opis ten przywołuje historię Rosji radzieckiej albo zapiski z Innego śmiata Gustawa Herlinga-Grudzińskiego czy wiele innych sprawozdań z sowieckiego systemu kontroli społecznej. Oczywiście, współcześnie poniższy fragment pasowałby także do działań amerykańskich, zważywszy na fakt, że USA mają najwyższy na świecie odsetek inkarceracji:

Wydawano olbrzymie sumy na kształcenie i przekonywanie tych umysłów, posługując się też tak zwaną kulturą czy, jak nazywało się to inaczej, literaturą i sztuką. Pewien z góry ustalony procent ludności trzymano wtedy w więzieniach, w barakach otoczonych drutami, czy też zsyłano na pustkowia, niekoniecznie dlatego, że ci właśnie, zamknięci, stanowiliby zarzewie buntu, bo tego nie dawało się dokładnie stwierdzić, sama jednak obawa trafienia za druty wywierała na resztę wpływ zbawienny (Miłosz 2012: 43).

W Górach Parnasu usiłuje więc Miłosz odzyskać myślenie symbolami w postaci racjonalnego Astronauty. Sam narrator twierdzi, że każdy nowoczesny umysł pragnie wrócić do myślenia symbolami. Zatem wysoce

\footnotetext{
${ }^{3}$ Odnajdujemy tę postawę również w zwięźle wyrażonym wpisie do Abecadła Miłosz̨a pod tytułem Ameryka, która jak starotestamentalny Lewiatan, „„[b]estia wychodząca z morza» powaliła w ciągu tego stulecia swoich kolejnych przeciwników i rywali. Najpoważniejszym z rywali była Rosja sowiecka, ponieważ w tym zderzeniu chodziło nie tylko o militarną siłę, ale o model człowieka. Próba stworzenia «nowego człowieka» wedle utopijnych zasad była gigantyczna, i ci, którzy ex post zbywaja ją lekko, zdają się nie pojmować, o jaką stawkę toczyła się gra. Wygrał «stary człowiek» i przy pomocy mass mediów narzuca swój wzorzec całej planecie. Patrząc z perspektywy, należy w sferze kultury szukać przyczyn sowieckiej klęski. Rosja, wydając astronomiczne sumy na propagandę, nie potrafiła przekonać do swego modelu nikogo, nawet w podbitych krajach Europy, które przyjmowały te jej próby szyderstwem, widząc w nich niezgrabne strojenia się barbarzyńców" (Miłosz 1997: 26).
} 
racjonalny Astronauta porzuca Związek i kryje się w komunie religijnej w Górach Parnasu, żeby żyć pod wpływem czasu, z którego wcześniej był wyłączony dzięki przedłużającym życie technologiom Związku Astronautów. Kontrola społeczna i atrofia języka, które chce przełamać Astronauta przez powrót do czasu, to podstawowe narzędzia disco imperiów.

\section{/// 5 .}

Kontrola społeczna i wyjaławiająca język kultura masowa fundują disco imperiów, czyli miejsce styczne inżynierii społeczno-kulturowej - zdaniem Miłosza - intensywnie aplikowanej po obu stronach muru berlińskiego, tak w USA, jak w ZSSR. To znaczy, cokolwiek o sobie wzajemnie mówią, oba ustroje angażują rozbudowane techniki kontroli społecznej poprzez kulturę, która traci na umasowieniu, bo powinna pozostać domeną wąskiej grupy „kapłanów”, jak chce narrator powieści.

Góry Parnasu moga jednak zwieść czytelnika sugestia, że dla Miłosza sztuka to wartość elitarna tworzona przez wąskie grono dla jego własnych celebracji. Tak rozumiana sztuka bliska jest koncepcjom XIX-wiecznego ruchu literackiego, który zawiera się w tytule powieści, czyli parnasizmowi, który apelował o doskonałość formalna, obiektywny refleksyjno-filozoficzny ton i elitarne wykształcenie poetów. Kult dla wytworów sztuki zastępował w tym światopoglądzie tradycyjną religię. W komentarzu do nowej liturgii przygotowanej przez postać Efraima przerażony narrator opowiada o kulturze nowoczesnej za pomocą metafory wielkiej hali z niekończącymi się rzędami fortepianów, na których wszyscy grają równocześnie, nie słuchając nawet najbliższego sąsiada. Narrator podsumowuje tę metaforę strasząc, że „powszechność sztuki nie była niczym innym niż wynikiem procesu alienacyjnego na masową skalę" (Miłosz 2012: 87-88).

Kosińska błędnie podąża tym tropem, ${ }^{4}$ choć sam Miłosz wielokrotnie jednoznacznie sprzeciwiał się takiej roli „,sztuki dla sztuki”. Przede wszystkim krytykowal elitaryzm i wsobność poezji przez negację postulatów parnasisty Stephana Mallarmégo, co najmocniej ujawnia się w wykładach harvardzkich Świadectwo poezji (1983). Mallarmé apelował o solipsystyczną poezję czystą, co Miłosz krytykuje jako eskapizm i narcyzm w obliczu nowoczesnej utraty kompasu etycznego: poeci czyści chcą umieścić poezję

\footnotetext{
${ }^{4}$ „[J]esteśmy też w momencie, w którym Rozum ludzki w cuglach technologicznego obłędnego wyścigu dochodzi do swego kresu i zwraca się przeciwko sobie [...] Miłosz pragnie oczyścić zaludnione przez artystycznych turystów, niegdyś niedostępne rejony Parnasu. Zdaje się mówić wprost: Góry Parnasu nie są dla setek tysięcy zarejestrowanych artystów, którzy żyją ze sztuki, ale dla nielicznych odszczepieńców, dla których sztuka jest życiem” (Kosińska 2012: 112, 123-124).
} 
poza tymi problemami poprzez jej przesunięcie wyłącznie na pole indywidualnego spełnienia artystycznego. To Miłosz nazywa „anty-światem”, bo nie wierzy w możliwość wydobycia czegokolwiek wyłącznie z siebie bez konfrontacji z interpersonalna ,wielką rodziną ludzką" (Miłosz 1983: 46). $\mathrm{XX}$-wieczni poeci, kontynuuje noblista, nie wierzą przecież ani w nieśmiertelność przez sławę czy pobożność, ani w to, że język odnosi się do czegoś więcej niż tylko do samych słów (Miłosz 1983: 48-49). Stąd w rozpaczy czepiać się mają „poezji czystej”, której powinniśmy się przeciwstawiać pisząc „poezję eschatologiczna”. Jak zatem rozumieć fragment z Liturgii Efraima? Jako część szerszej refleksji Miłosza wypowiedzianej przez stworzona przez niego postać, niepowiązana jednoznacznie z autorem.

\section{/// 6 .}

Czy zatem Miłosza prorokowanie o przyszłości kultury przynosi jednoznaczne odpowiedzi? Nie, bo jest niedokończone. Czy możemy je wypunktować? Jedynie fragmentarycznie i powierzchownie, bo wyglądanie w przyszłość zawsze pozostaje mgławicowe. Przyszła kultura ma być pozbawiona artystycznego kapłaństwa nielicznych, do której dostęp mają wszyscy prosumenci, czyli nowocześni twórco-odbiorcy kultury, równocześnie jej producenci i konsumenci: „Kiedyś wiele rozprawiano o «twórcach» i «odbiorcach», teraz jednak wyrazy te stały się całkiem bezużyteczne, jako że pozostali sami «twórcy»" (Miłosz 2012: 87). Swoją drogą, koncepcję prosumpcji proponowali cztery lata po Miłoszu, w 1972 roku, Marshall McLuhan i Barrington Nevitt; co znaczy, że kwestia była istotna i zauważalna. Pod względem uchwycenia prosumpcji jako novum kultury refleksja Miłosza okazała się wspaniale prorocza, bo taki właśnie obrót rzeczy przyniosła internetyzacja i ulinkowienie rzeczywistości, w której globalne korporacje medialne cedują na użytkowników „,kontentu” jego wytwarzanie, podczas gdy same zarabiają na pośrednictwie i reklamach.

Należy jednak pamiętać, że tego wniosku Miłosz nie zawarł w swojej powieści fantastycznonaukowej - jak chciałaby Kosińska - lecz we wcześniej wydanej Liturgii Efraima. Tym niemniej, same Góry Parnasu prorokuja o przyszłości kultury w ramach futurologicznej refleksji filozoficzno-religijnej. Mówią jednak bardziej ogólnie: patrzmy szerzej, bądźmy uważni na drugiego człowieka, ograniczajmy się, wycofujmy, bo kultury będzie coraz więcej i coraz mniej będziemy słyszeć. Możemy więc jedynie znaleźć dla siebie przyczółki kontemplacji i obserwacji przebiegów czasu i historii. 
Miłosz nie kończy Gór Parnasu, bo jak twierdzi, ,wynik byłby 1) artystycznie wattpliwy 2) niemoralny" (Miłosz 2012: 21). W swoim anglojęzycznym wykładzie dla Uniwersytetu Michigan pod tytułem $A$ Poet Between East and West (Miłosz 1976) - później w przekładzie pod tytułem Niemoralność sz̨uki w zbiorze esejów Życie na wyspach (1997) - Miłosz podkreśla swoją sytuację pomiędzy, ale też wyjaśnia, że prawdziwa sztuka i poezja jest zawsze nieodłącznie niemoralna. To zaskakujące stwierdzenie oznacza jednak według pisarza, że sztuka potrafi przekazać konkretną wartość tylko wtedy, kiedy wykroczy poza to, co powszechnie uzgodnione, i wskaże na coś nieludzkiego, coś niewpisanego w dominującą moralność czy ideologię. Dla Miłosza prawdziwa sztuka i poezja to właśnie te, które zajmują się rzeczywistością, a - jak można wywnioskować z Niemoralności sæ̨tuki - w tym okresie rzeczywistość dla Miłosza to ideologiczne konstrukcje bięacych wydarzeń społecznych. Podsumowując zatem, Góry Parnasu wprost mówią o kierunku wydarzeń społecznych, ale dla Miłosza bez wystarczającego kunsztu artystycznego, żeby zasłużyć na publikację. Z drugiej strony, być może autor chce w tym wypadku opisać kwestie na tyle moralne, że woli do tego nie zaprzęgać nieodłącznie niemoralnej sztuki? Czy nie znaczy to, że dzięki materiałom wydobytym $\mathrm{z}$ archiwów biblioteki Beinecke nie świadkujemy sytuacji, w której Miłosz zatrzymuje się w pół kroku, między artystycznym wypełnieniem a refleksją moralną, profetyczną wizyjnością a filozoficzna powściąliwością?

\section{$/ / / 8$.}

Prócz ogólnoimperialnej praktyki kontroli społecznej przez kulturę popularną, moje określenie disco imperiów równocześnie zawiera w sobie niechęć poety do samego gatunku fantastyki naukowej jako wytworu kultury popularnej. Miłosz miał bardzo negatywną opinię na temat gatunku literatury fantastycznonaukowej, którą ujawnia na pierwszych kartach Gór Parnasu. Postrzega go jako dziecko XIX-wiecznych przełomów w nauce, które zainspirowały wiarę w nieograniczony rozwój technologiczny. XX wiek dodał do tego wizje społeczeństwa przyszłości, zazwyczaj pesymistyczne (por. Miłosz 1970: 5). Tym niemniej, narrator wprowadzający do tej fragmentarycznej powieści wyznaje swoją wiarę w szczęśliwe zakończenie: „Moje rozdziały nikogo nie pociesza, wypada jednak wspomnieć, że w moim zamyśle cykl, w którym ludzkość straciła i nadzieję, i poczucie ciągłości historycznej, właśnie dobiega końca” (GP 23). 
Według noblisty fantastyka naukowa zaczyna się tam, gdzie przestrzeń przestaje stymulować wyobraźnię, a tę rolę przejmuje od przestrzeni czas. Zaznacza w eseju z tego samego okresu, Science fiction i przyjscie Antychrysta, że science fiction może być „szczególnie użyteczna kiedy zastanawiamy się nad zasięgiem ludzkiej wyobraźni” (Miłosz 1970: 7), choć, „[m]imo że większość utworów science fiction jest bez większej literackiej wartości, gatunek zdaje się zwyciężać w konkurencji z tzw. powieścią współczesną" (tamże: 6). W listach Miłosz przyznaje, że napisałby powieść, ale to niemożliwe w Ameryce; nawet jeśli jedyną fabuła, której mogłaby dostarczyć mu Ameryka, nadawałaby się tylko na powieść fantastycznonaukową - stąd dwuznaczność i niewypełnienie próby jej napisania.

To znaczy, że Miłosz postrzegał gatunek negatywne, mimo to go użył, próby go nie zadowoliły, więc za radą redaktora naczelnego paryskiej „Kultury", Jerzego Giedroycia, skrzętnie schowal je do archiwum. Góry Parnasu nie mają być literaturą popularną i stanowią science fiction, bo usiłują sprostać zadaniu Miłosza, czyli przesunąć refleksję z władzy nad czasem przyszłym na poddanie się umykającej doczesności. To znaczy, że fantastyka naukowa wyobraża nieustający rozwój ludzkości - korzystny lub niekorzystny - jako nieustającą zmianę, rozwój, staranie, które niesie nadzieję na jakiegoś rodzaju trwałość w świecie ziemskim. Jednak Miłosz pragnie ten czas zatrzymać na sposób niemal średniowieczny, czyli wskazać, żebyśmy myśleli o przyszłości jako niezmiennej części wszechogarniającej wieczności, sub specie aeternitatis, która niweluje jakikolwiek rozwój, zmianę i staranie.

W tym rozumieniu powieść Miłosza to raczej anthropological fiction, fikcja na temat przyszłości ludzkości, refleksja nad ludzkim gatunkiem i jego eschatologicznym losem. Dlatego też przy pierwszej lekturze tak trudno zrozumieć użycie science fiction przez Miłosza: zachowując fantastycznonaukowy sztafaż, przeczy jego naczelnej zasadzie czasowości i wskazuje rozmyślanie nad przyszłością jako podstawowy błąd kultury. Nie zmienia to faktu, że cała ta postawa pozwala mu aspirujący do racjonalności gatunek literacki przybliżyć do refleksji religijnej. To działanie jest zupełnie zgodne z jego trwała potrzebą wykazywania bliskości nauki i religii, co pojawia się szczególnie silnie u Miłosza w niewiele późniejszej Ziemi Ulro (1977), ale też w poetologicznym Świadectwie poezji.

Jak Miłosz notuje w Science fiction i przyjściu Antychrysta, w fantastyce naukowej „wyraźnej linii granicznej pomiędzy wyobraźnią zorientowana technicznie i refleksją filozofów nie dałoby się przeprowadzić” (Miłosz 1970: 5). A przez refleksję filozoficzną Miłosz ma na myśli taką, która angażuje się w doświadczenie religijne. Fantastyka naukowa miałaby być 
szczególnie właściwym gatunkiem, żeby łączyć filozofię i doświadczenie religijne poprzez bliskość wizyjnej przyszłości i wyobraźni chrześcijańskiej, o której Miłosz pisze:

Bo chociaż laboratoria dziewiętnastowiecznych uczonych zrodziły nowy literacki gatunek, od wieków chrześcijański folklor gromadził oznaki zbliżającego się jednego kluczowego wydarzenia: drugiego przyjścia poprzedzonego przyjściem Antychrysta, millenium, końca czasów. Być może dzisiejsze science fiction tłumaczy się właśnie tym, że zastaje ona grunt przygotowany, wykorzystując stare złoża w podświadomości, co łączy ją z folklorem (Miłosz 1970: 8).

\section{/// 9.}

W Science fiction i przyjściu Antychrysta Miłosz twierdzi, że zarówno fantastyka naukowa, jak i proroctwa pisane są jakby już się wydarzyły, w czasie przeszłym, który sprawia, że przepowiednia, „(bo przecie chodzi tu o przepowiednię) jest gramatycznie zamaskowana" (1970: 6). Z powodu tego zacierania granicy między naukowym a religijnym Miłosz może użyć gatunku science fiction, żeby wykorzystać silną w polskiej literaturze tradycje prorokowania.

Prorok to bard z misja. Tradycyjnie, prorok wskazuje na kryzys tradycji społeczności, niemoralne zwyczaje czy wykroczenie przeciw woli Boga i nawołuje do zmiany, reformy politycznej lub religijnej, a nawet do rewolucji. Miłosz prorokami nazywa polskich poetów romantycznych, ale głównie w asocjacji negatywnej $j^{5}$. Natomiast w jego oczach prorokami sa nie

\footnotetext{
${ }^{5}$ O prorokowaniu u Miłosza pisało wielu polskich badaczy, m.in. Elżbieta Kiślak czy Jan Błoński. Figura proroka bliższa jest Miłoszowi niż wieszcza czy barda, choć nie dominuje całości jego dzieła, lecz raczej jego polską recepcję. Miłosz używa terminu 'prorok' w odniesieniu do prawdy oraz jako bard narodu żydowskiego. Miłosz używa tego terminu dwa razy częściej niż 'wieszcz'. Poza zastosowaniem stricte biblijnym, noblista wprowadza ten termin na określenie poetów romantycznych jako wizjonerów przyszłości nacjonalistycznej, przecież tuż przed wojną w wierszu Pieśn niedobrych synów podmiot zwraca się do Polski „Kraino smutna, rozdarta i dzika, / Matko proroków, ojczyzno mścicieli” (Miłosz 2015: 142). A w późnym autorefleksyjnym Ze sækoda (2000) mówiący wskazuje na zagrożenia poezji w kręgu kultury polskiej, gdzie każde słowo wielbionego autora może zostać wykorzystane do politycznego zysku czy nacjonalistycznego szaleństwa, jak stało się z pismami Mickiewicza: „Piszmy dla siebie, dla paru przyjaciół. / Żeby umilić niedzielną majówkę. / Tak się zaczyna. A później sztandary, / Wrzaski, proroctwa, obrona barykad” (Miłosz 2015: 1196). Innym słowem w kontekście prorokowania jest 'wajdelota' albo 'wajdalota', jak używa go Miłosz. Według słownika Doroszewskiego wajdelota to „niższy kapłan u pogańskich Litwinów, zarazem śpiewak, bard”, słowo często używane przez Mickiewicza, pochodzi od niemieckiego Waidleri staropruskie-
} 
tylko poeci, ale także myśliciele, którzy potrafią wpłynąć na rzeczywistość swoimi słowami ${ }^{6}$. Wreszcie Miłosz sugeruje samego siebie jako potencjalnego proroka, który miałby ujawniać kryzys i potrzebę zmiany, rozumiane jako opis bieżących wydarzeń z perspektywy przeszłości i przyszłości - jak w Górach Parnasu - ale raczej nie na planie politycznym, tylko metafizycznym. Jest to jednak wyjątek, który potwierdza regułę wstrzemięźliwości i niechęci Miłosza wobec prorokowania. Podmiot mówiący wiersza Nie mój (1997) tłumaczy, dlaczego nie unika jawnego nawoływania do przemiany nowoczesnej rzeczywistości: „Gdybym wrzasnął / I zaczął prorokować, nikt by nie usłyszał. / Nie na to ich ekrany, mikrofony. / Tacy jak ja błądzą ulicami / I mówią do siebie" (Miłosz 2015: 1135). Nie mówiąc już o sytuacjach, kiedy sam Miłosz fetowany był w roli wieszcza w Gdańsku w roku 1981 czy w trakcie jego krakowskiego pogrzebu w roku 2004. Dość powiedzieć, że podmiot mówiący w piątej części Traktatu teologicznego (2002) sam obawia się, że zostanie upolityczniony właśnie w takich rytuałach jak prawodawca polskiego romantyzmu: „Ten Mickiewicz, po co się nim zajmować, jeżeli i tak jest wygodny. // Zamieniony w rekwizyt patriotyzmu dla pouczania młodzieży. // W puszkę konserw, która po otwarciu miga scenami kreskówki o dawnych Polakach” (Miłosz 2015: 1284).

\section{/// 10.}

Rewolucyjna iskra romantyzmu w krajach niepodległych wspierała wektor introwertyczny $\mathrm{i}$ indywidualistyczny, ale w społecznościach podległych jak Polska realizowała się w politycznym aktywizmie. Od Williama Wordswortha (1770-1850), poety najważniejszego dla brytyjskiego romantyzmu refleksyjnego, Mickiewicz wolał politycznego Georga Byrona (1788-1824), którego poemat Giaur (1813) sam przełożył. Prorok potrafi łączyć oba kierunki, bo projektuje przyszłość dzięki introwertycznej refleksji o rzeczywistości. Ta postać jednak w polskiej tradycji wyłania się w sposób niejedno-

go czasownika waidlemai, 'przewidywać'. Tym słowem Miłosz określa pisarzy ze swojego regionu, Adama Mickiewicza, Cypriana Kamila Norwida, Witolda Gombrowicza, Teodora Bujnickiego czy samego siebie: „Nikt z wajdalotów nie wrócił do rozmowy ojców swoich. / [...] / Pan Narwid na przykład, pan Gombrys, obaj z żemojtskiej ziemie. / Nie litewscy jesteśmy poeci, ani ja, ani Litwin Teodor" (Miłosz 2015: 672-673). W tym użyciu 'wajdalota' sugeruje prowincjonalizm i silne lokalne ukorzenienie.

${ }^{6}$ Z tego powodu Miłosz nazywa prorokami także mistrzów podejrzeń, Karola Marksa (1818-1883) i Fryderyka Nietzschego (1844-1900), bo mieli zaproponować samospełniające się przepowiednie, wpływając na historię jeszcze zanim cokolwiek się wydarzyło (Miłosz 2015: 430, 950). Co ciekawe, do tej samej grupy Miłosz zalicza filozofa religii Jakuba Böhmego (1575-1624) i brytyjskiego poetę-mistyka Williama Blake’a (1757-1827; Miłosz 2015: 1291, 1351). 
znaczny. Romantycy łączyli przeciwieństwa, które można podzielić między dwa bliskoznaczne określenia z epoki - barda i wieszcza - których pola semantyczne i kulturowe użycie częściowo pokrywają się z właściwościami proroka. Bard wygląda ku przeszłości, ale też konfrontuje się z teraźniejszymi podziałami w społeczeństwie klasowym? Wieszcz ma wspierać spójność etniczna, wyobrażać wspólnoty, ale też formułować nowe religie i mitologie w miejscach wyjałowionych przez rozum. Bard konfrontuje się $z$ uniwersum rządzonym przez interes i pieniądze.

Jak sam Miłosz przedstawia to w swojej Historii literatury polskiej, wieloletni rozwój kultury w podległości nałożył na pisarza rolę charyzmatycznego przywódcy, który powinien ucieleśniać starania polityczne całego narodu, co nierzadko nieodróżnialne było od praktyk religijnych (Miłosz 1969: 203). Ze względu na silną rolę tradycji katolickiej polski wieszcz narodowy odnajduje się w roli biblijnego barda, czyli proroka, który łączy w sobie pragmatyczne elementy polityczne i religijne. Powołanie wieszcza pochodzi ze wspólnotowej potrzeby przywódcy w bezpaństwowej kulturze oraz z zależności od wyobraźni i słowa literackiego jako nośników autentycznej reprezentacji rzeczywistości. Polski wieszcz powinien więc mierzyć się z kwestiami politycznymi przez język religii oraz głosić kulturę ojczyzny po obcych krainach. Nieodzowna przypadłościa polskiego wieszcza jest przecież wygnanie. Wieszcz jako bard musi być pamięcia narodu, a jako prorok - jego sumieniem. Wieszcz jako bard mierzy się z estetycznym, a jako prorok $-\mathrm{z}$ etycznym postrzeganiem prawdy. W polskiej tradycji wieszcz nie tylko prze-widuje czasy politycznej wolności, ale też prze-widuje polityczną wolność przez religijne ocalenie. Zatem w czas podległości tekst poetycki uzyskuje wartość proroctwa o przyszłym wyzwoleniu. Wieszczenie narodowego odrodzenia spełnia się jednak wyłącznie poprzez wielbienie polskiej kultury. Innymi słowy, narracja polskiego mesjanizmu - zgodnie z która podległość Polski jest ofiarą na rzecz wolności innych ludów - implikuje konkretną rolę poety: on (nie ona) ma być wieszczem wielbiącym kulturę jako samozwrotne, narcystyczne utożsamienie.

\footnotetext{
7 Angielskie słowo 'bard' pochodzi od negatywnie nacechowanego, szesnastowiecznego szkockiego określenia na wędrownych muzyków, których następnie romantyzował Sir Walter Scott (1771-1832), prawodawca wyspiarskiego folkloru w tradycji epickiej. Miłosz używa określenia 'bard' rzadko i zazwyczaj negatywnie, np. mianując poetę Konstantego Ildefonsa Gałczyńskiego piewcą polskich środowisk nazistowskich: „W czasie kiedy skrajna prawica przyciagała większość publicznej opinii, ofiarował tej prawicy swój wielki talent i stał się jej bardem. [...] [Po wojnie] został jednak bardem nowej, komunistycznej Polski. Jego instynkt i potrzeba kierowały go tam, gdzie mógł znaleźć masy" (Miłosz 2015: 419). To użycie występuje wyłącznie w kontekście poety jako ideologa ruchów masowych, które miał wyobrażać przez włączanie, wyłączanie i podziały między i wewnątrz społeczności.
} 
Stąd poeci najważniejsi dla polskiej społeczności w stanie podległości nazwani zostali przez nią ,wieszczami narodowymi” (por. Miłosz 1969: 197, 201) ${ }^{8}$. Polski wieszcz narodowy ucieleśnia i kierunkuje dyskursy społeczności. W tym celu polscy wieszcze mieli używać siły wyobraźni. Wyobraźnia porusza ludzi wbrew racjonalnym argumentom, co romantycy opisywali jako odrębną siłę przyrody - część nas samych. Każdy ma wyobraźnię, więc łączy ona wszystkich ludzi, niemal egalitarnie każdemu pozwalając zostać wieszczem narodowym, przywódcą społeczności; zupełnie jak żołnierze Napoleona nosili buławę generalską w plecakach, czyli mieli szansę awansować za dokonania w walce. Wyobraźnia to zatem społeczna siła, którą każdy może uruchomić. Świetne przykłady pracy wyobraźni odnajdujemy w przednowoczesnych mitologiach i folklorze jako przedracjonalnych punktach odniesienia zamkniętych w poezji, wystarczy przypomnieć sobie istotność Homera, Wergiliusza czy nawet fikcyjnego Osjana albo kolekcji braci Grimm. Ci ostatni są przykładem tej części romantycznego ruchu, która zawierała wysiłek poszukiwania i ratowania przekazów ustnych, żeby uchronić skarby wyobraźni przed wartkozmiennym prądem nowoczesności.

Prócz Ksiag narodu i pielgrzymstwa polskiego (1832) wieszcz Mickiewicz pracował nad tekstem protofantastycznonaukowym, który miał być raczej profetyczną medytacją nad przyszłością ludzkości w historii, oczywiście w kontekście Polski. W odróżnieniu od wieszcza Mickiewicza Miłosz nie porusza w Górach Parnasu żadnych wątków mesjanistycznych; a nawet gdy-

\footnotetext{
${ }^{8}$ Najpopularniejsza nazwa romantycznych poetów, 'wieszcz', znaczy w słowniku Doroszewskiego „natchniony, genialny, wybitny poeta”, co typowo wskazywało na Adama Mickiewicza, Juliusza Słowackiego i Zygmunta Krasińskiego - i w takim rozumieniu najczęściej używa go Miłosz (np. Miłosz 2015: 360). 'Wieszcz' pochodzi jednak od przestarzałego „wieszczbiarz” - jak pisze Doroszewski - czyli kogoś „obdarzonego przez bogów darem widzenia przyszłości”. Zatem wieszcz jako bard, jasnowidz, prorok ma być tym, który zbiera wszystkie czasy społeczności; tym, który przekazuje tradycje przeszłości, daje słowo wydarzeniom teraźniejszości i kreśli kontury przyszłości. Miłosz zastanawiał się nad użyciem tego określenia w stosunku do Williama Blake’a: „Na określenie Blake’a nie ma w polskim języku wyrazu, jeżeli odrzucimy zbyt zużyte «wieszcz» i zbyt lekkomyślne "wizjoner»" (Miłosz 1981: 13). W Ziemi Ulro refleksje Miłosza zbliżają wieszcza do proroka. Jerzy Jarzębski zastanawia się w swoim tekście Być wiesžczem, co to znaczy, że Miłosz może być wieszczem. Argumentuje, że Mickiewicz uważany był za największego poetę nie ze względu na umiejętności pisarskie, ale osobowość, wizję i biografię niezmiennie wpisane w jego dzieło, modelowane przez niego na wzorcowy los wędrownego poety-rewolucjonisty. Od Mickiewicza, kontynuuje Jarzębski, każdy pretendent (sic!) do tronu najlepszego polskiego pisarza pozycjonuje się względem zmitologizowanej funkcji wieszcza. Jarzębski jednak pomija fakt, że wieszcz konserwuje wyidealizowaną wersję wartości narodowych, ale w oderwaniu od drobnomieszczańskiej codzienności społecznych zatrudnień, dzięki czemu przyjmuje zdystansowaną perspektywę na wydarzenia w domu. Dzięki temu każdy wieszcz powstaje głównie poza polską społecznością, w procesie eksternalizacji kultury, która następnie zostaje wtórnie zinternalizowana przez procesy dostosowawcze instytucji narodowych.
} 
by je wprowadził, to zgodnie z refleksja w innych tekstach - jedynie jako krytykę wątku w kulturze, który wyniszcza potencjał polskiej społeczności. Niestety, wieszcza Mickiewicza polsko-francuska proza L'bistoire d'avenir (Historia przyszłości) nigdy nie została odnaleziona, bo podobnie jak Miłosz, autor nie był z niej zadowolony i prawdopodobnie sam ją zniszczył. Widać polskim poetom politycznym nie dane jest być kronikarzami przyszłości.

Bibliografia:

/// Andrzejewski J., Miłosz Cz. 2011. Listy 1944-1981, oprac. B. Riss, Biblioteka Więzi.

/// Bielik-Robson A. 2013. Mała gnostycka pielgrrymka, http://krytykapolityczna.pl/felietony/agata-bielik-robson/mala-gnostycka-pielgrzymka/2013/; dostęp: 18.10.2018.

/// Bill S. 2017. Translator's Introduction, [w:] Cz. Miłosz, The Mountains of Parnassus, Yale University Press.

/// Garbol T. 2014. Oeconomia divina Cžesława Mitosza jako projekt dystopii, „Prace Filologiczne. Literaturoznawstwo”, nr 4 (7), s. 383-396.

/// Giedroyc J., Miłosz Cz. 2011. Listy 1964-1972, oprac. M. Kornat, Czytelnik.

/// Jarzębski J. 1981. Być wiesz̧rzem, „Teksty”, nr 4-5 (58-59), s. 234-267.

/// Jarzyńska K. 2013. Pochwała ograniczeń, czyli Miłosz̨a próba antyutopii, „Nowa Dekada Krakowska”, nr 3, s. 130-141.

/// Kołodziejczyk E. 2001. Popularna twarz Ulro: o „Kulturze masowej” - antologii Cžesława Miłosza, „Teksty Drugie”, nr 3/4, s. 115-124.

/// Kosińska A. 2012. Prorok Nowego Świata, [w:] Cz. Miłosz, Góry Parnasu, Krytyka Polityczna, s. 108-127.

/// Miklas-Frankowski J. 2014. Góry Parnasu Czesława Mitosza jako próba gnostyckiej dystopii, „Estetyka i Krytyka”, nr 35, s. 29-48.

/// Miłosz Cz. 1959. Kultura masowa, Instytut Literacki.

/// Miłosz Cz. 1968. Liturgia Efraima, „Kultura”, nr 8-9, s. 250-251.

/// Miłosz Cz. 1969. The History of Polish Literature, Macmillan. 
/// Miłosz Cz. 1970. Science Fiction i przyjście Antychrysta, „Kultura”, nr 12, s. 279.

/// Miłosz Cz. 1976. A Poet Between East and West, „Michigan Quarterly Review", nr 3, t. XVI, s. 263-271.

/// Miłosz Cz. 1981. Ogród nauk, Instytu Literacki.

/// Miłosz Cz. 1983. The Witness of Poetry, Harvard University Press.

/// Miłosz Cz. 1997. Abecadto Miłosza, Wydawnictwo Literackie.

/// Miłosz Cz. 2012. Góry Parnasu, Wydawnictwo Krytyki Politycznej.

/// Miłosz Cz. 2015. Wiersze wszystkie, Znak.

/// Zioło M. 2014. O - jak oprz̨ęrenie, „Więź”, nr LVII, s. 152-155.

\section{/// Abstrakt}

Artykuł skupia się na krytyce, której Czesław Miłosz poddaje rozrywkę imperialnych społeczeństw lat 70. XX wieku. Celem refleksji jest opis tego, jak doświadczenie imperiów jawi się w antropologicznym science fiction noblisty pt. Góry Parnasu, które ukazało się pośmiertnie w roku 2012 (pisane 1968-1972). Tekst nigdy niepublikowanej powieści zdawać by się mógł krytyką kapitalizmu amerykańskiego i rozruchów studenckich z okresu kontrkultury, lecz wiele fragmentów wskazuje także na sowiecką Rosję. Jego doświadczenie styku imperium i rozrywki zarówno w Polsce, jak i za granica uwrażliwiło go na przecięcie się społecznej standaryzacji, nieludzkości nauki i religijnego zbawienia. Artykuł eksploruje to złożone równanie zawarte nie tylko w powieści, lecz także w innych pismach polskiego poety $\mathrm{z}$ lat 70. XX wieku, w których podobnie ujawniają się problemy kondycji ludzkiej. Choć Miłosz nie zdołał wypełnić popularnoliterackich zobowiązań gatunku, to jednak jego krytyka przyziemnej zabawy jest o wiele silniejsza w Górach Parnasu, niż w którymkolwiek z innych jego dzieł. W tej powieści Miłosz uznaje kulturę popularną za przegrany projekt, a antidotum proponowane ze strony państwa - za społeczną standaryzację. Rzucając swoja refleksję nad społeczeństwem w przyszłość, Miłosz wykorzystuje gatunek fantastyki naukowej, żeby przekazać wyobrażenie o rozwoju kultury. Tak użyte science fiction nie urzeczywistnia swojego potencjału znanego z kultury popularnej, jednak wciąż stanowi niezwykły prognostyk o przyszłości 
kultury, który wywodzi się z romantycznych źródeł wieszczenia o stanie społeczeństwa i wyobrażania sobie jego właściwej przyszłej tożsamości.

Słowa kluczowe:

Miłosz, kultura, przyszłość, romantyzm, prorok, prorokowanie

\section{/// Abstract}

\section{Imperial Disco: Czesław Miłosz and the Future of Culture}

The article focuses on Czesław Miłosz's criticism of the entertainment of the 1970s imperial societies. The aim is to describe how the experience of empires appears in Miłosz's anthropological science fiction, The Mountains of Parnassus, which appeared posthumously in 2012 (written 1968-1972). The text may seem to be a critique of American capitalism and counterculture's student riots, but many passages also point to Soviet Russia. Miłosz simultaneously writes about both empires. His experience of tangential points of empire and entertainment in Poland and abroad made Miłosz more sensitive to the crossroads of social standardization, inhumanity of science, and religious salvation. The article explores this complex equation contained in the novel as well as other Miłosz's 1970s writings which also reveal the problems of the modern human condition. Although Miłosz failed to fulfill the commitments of the science fiction genre, his criticism of mundane play is much stronger in The Mountains of Parnassus than in any of his other works. In this novel, Miłosz considers popular culture a lost project and a state-instituted antidote of social standardization. By reflecting on the future of the society, Miłosz uses science fiction to convey his image of the development of culture. Such science fiction does not realize its potential known from popular culture, but it still is an extraordinary prognosis about the future of culture derives from the romantic sources of foreseeing the state of society and imagining its future identity.

Keywords:

Miłosz, culture, future, Romanticism, prophecy, prophet 
/// Mikołaj Golubiewski - literaturoznawca, tłumacz, współpracownik Wydziału „Artes Liberales” Uniwersytetu Warszawskiego. Zajmuje się polską szkoła poezji w kulturze anglo-amerykańskiej, robotami w nowoczesnej kulturze europejskiej, literatura światową i przekładem naukowym. Redaktor publikacji zbiorowych Rilke po polsku, Doświadczenie nowoczesności i A Handbook of Dialogue. W 2018 ukazała się jego pierwsza monografia The Persona of Czesław Mitosz.w wydawnictwie Peter Lang. Absolwent Instytutu JFK na Wolnym Uniwersytecie w Berlinie (2016), stypendysta niemieckiego programu rządowego Exzellenzinitiative (2012-2016) i Institute of World Literature na Uniwersytecie Harvarda (2013), Non-Graduate Visiting Student na Uniwersytecie Chicago (2015).

Email: mgolubiewski@gmail.com 